\title{
Performed Lesion Description Measurable Indicator
}

National Cancer Institute

\section{Source}

National Cancer Institute. Performed Lesion Description Measurable Indicator. NCI

Thesaurus. Code C93927.

Specifies whether a lesion or site of disease is measurable. 